\title{
Exocrine Pancreas Function in Premature and Full Term Neonates
}

\author{
G. Zoppi ${ }^{321}$, G. Andreotti, F. Pajno-Ferrara, D. M. Njai, and D. Gaburro \\ Clinica Pcdiatrica della Università di Padova, Sede di Verona, Verona, and Istituto di Puericultura della Università di Ferrara, Ferrara, Italy
}

\begin{abstract}
Extract
Pancreatic response to pancreozymin and secretin stimulations has been studied in premature and full term neonates. The following results have been obtained. (1) At birth premature neonates have a fairly well developed exocrine pancreatic function which is, however, lower than that of full term neonates. (2) One week after birth, exocrine pancreatic activity becomes higher in premature than in full term neonates. (3) Early administration of small amounts of starch stimulates pancreatic $\alpha$-amylase (EC. 3.3.1.1) production. (4) A high protein diet stimulates increased production of both trypsin (EC. 3.4.4.4) and lipase (EC. 3.1.1.3), whereas a high fat diet alone has no effect on lipase secretion.
\end{abstract}

\section{Speculation}

Exocrine pancreatic function is fairly well developed in premature neonates from 32week gestation, although it is less developed at birth than it is in full term neonates and in older infants and children. After birth, the more rapid maturation of the exocrine pancreas function of premature neonates is probably related to the functional demands of a more rapid growth. The rates of maturation of secretion of $\alpha$-amylase and trypsin increase proportionately to the starch and protein contents of the diet. The use of an appropriate diet therefore seems to be of great importance in regulating the secretions of the exocrine pancreas during the first month of life.

\section{Introduction}

A quantitative evaluation, under physiological conditions, of exocrine pancreas function in neonates, during the first days after birth is, in our opinion, very important in order to assess the intraluminal phase of intestinal digestion and absorption during this period. Exocrine pancreas function is known to be controlled by many factors. In animals, synthesis of pancreatic enzymes in particular has been shown to be influenced by diet $[5,7,8,10,13,16,18]$. This influence has been demonstrated in children only after such serious disorders as malnutrition $[2,6]$. In this work we have studied (1) the basal exocrine pancreatic function in "healthy" premature and full term neonates, and (2) modification of this function by diets containing starch or relatively large amounts of protein and fat.

\section{Materials and Methods}

\section{Subjects Studied}

We studied 36 premature infants (22 females, 14 males) of 32 - to 34 -week gestational (postmenstrual) age with birth weights of $2.0-2.4 \mathrm{~kg}$ (mean $=2.15 \mathrm{~kg}$ ) and 8 full term infants ( 5 females and 3 males) with birth weights of $3.6-4.0 \mathrm{~kg}$ (mean $=3.68 \mathrm{~kg}$ ). The subjects were considered healthy as none presented 
signs of neurologic or respiratory disturbance and all had Apgar scores of 10. Subjects were first tested 2-6 hr after birth before the first feeding, again $24 \mathrm{hr}$ thereafter (i.e., after 6 meals during $18 \mathrm{hr}$ and $6 \mathrm{hr}$ of fasting), and for a third time when they were l-wk-old (after 6 hours' fasting). Premature infants were also tested again at the age of 1 month. Permission for studying these subjects was obtained from the parents after a full explanation of the procedure. During the study the patients were fed the following formulas (Table I): (1) 16 premature neonates and 8 full term infants, S 26 Wyeth (formula $A$ ); (2) 6 premature neonates, commercial skimmed milk with addition of $2 \mathrm{~g}$ soluble starch $/ 100 \mathrm{ml}$ (formula $B$ ); (3) 5 premature neonates, the same commercial skimmed milk with the addition of $2 \mathrm{~g}$ glucose $/ 100 \mathrm{ml}$ so that it was isocaloric with formula $B$ (formula $C$ ); and (4) 9 premature neonates, the same commercial skimmed milk without any addition (formula $D$ ).

For evaluation of the degree of maturity of exocrine pancreatic function in premature and full term neonates, we used the values obtained previously for older infants and children who were 3 months to 13 years of age [23].

\section{Duodenal Intubation}

For the collection of duodenal juice we used a specially manufactured three-lumen tube [24] with a 3.5$\mathrm{mm}$ external diameter. Incorporated in the tube are two smaller channels connected to two inflatable rubber balloons and a larger central lumen for the collection of duodenal juice. The distal balloon is at the end of the tube and the other is located $2 \mathrm{~cm}$ proximally. There are silver markers before the proximal balloon and after the distal one (Figs. 1 and 2). The tube was introduced into the duodenum under fluoroscopic control so that the distal marker was situated near the ligament of Treitz and the proximal one in the first part of the duodenum (Fig. 3). Usually no sedation of patients was necessary. The balloons were then inflated with $2 \mathrm{ml}$ air. We started sampling only if the duodenum was completely isolated from the stomach and the jejunum, i.e., if 4-5 $\mathrm{ml}$ air introduced into the lumen could be completely recovered. After an initial collection of duodenal juice for 10-20 min, exocrine pancreas secretion was stimulated, as in our previous investigations $[9,22,23]$, with pancreozymin [25] and 20 min later with secretin [25]. Both hormones were administered by slow intravenous injection (1 min). Duodenal juice was obtained by continuous gentle aspiration and was immediately collected into different
Table I. Composition of the formulas ${ }^{1}$

\begin{tabular}{lcccc}
\hline & Formula $A^{2}$ & Formula B & Formula $C$ & Formula D \\
\hline Carbohydrates & & & & \\
$\quad$ Lactose & 7.0 & 6.72 & 6.72 & 6.72 \\
$\quad$ Glucose & & & 2.00 & \\
$\quad$ Starch & & 2.00 & & \\
Protein & 1.5 & 4.08 & 4.08 & 4.08 \\
Fat & 3.6 & 0.12 & 0.12 & 0.12 \\
Minerals & 0.25 & 0.84 & 0.84 & 0.84 \\
Calories & 66.4 & 51.3 & 51.3 & 43.3 \\
\hline
\end{tabular}

1 Values are expressed as grams per $100 \mathrm{ml}$ of reconstituted milk.

${ }^{2}$ Formula A: S 26 Wyeth.

ice-cooled flasks during each of the five subsequent 10min periods (two 10-min collections after pancreozymin and three 10-min collections after secretin injection). No disturbance was observed in any of the subjects during or after the pancreatic function test.

\section{Laboratory Procedures}

On each 10-min sample of duodenal juice, volume, $\mathrm{pH}$, and lipase activity were measured immediately after collection. Trypsin and $\alpha$-amylase activities were determined after samples had been stored at $-25^{\circ}$. The methods used were: continuous titration according to Marchis-Mouren et al. [14] for lipase activity, spectrophotometry according to Lundh [12] for trypsin, and colorimetry as described by Meyer et al. [15] with the modification of Dahlqvist [4] for $\alpha$-amylase. The enzymatic activities of lipase and $\alpha$-amylase are expressed as international units [26], and that of trypsin as micrograms of crystalline bovine enzyme [27]. The secretory response to pancreozymin and secretin is expressed as total volume of the duodenal juice and enzymes per kilogram body weight per $50 \mathrm{~min}$.

\section{Results}

In Table II are reported the results obtained with the premature neonates who were fed formula $A$. At birth before the first feeding, the trypsin, lipase, and $\alpha$-amylase activities were fairly high, although markedly lower than in older infants and children. Twenty-four hours after the first feeding, the values were slightly lower. In 1-week-old infants, the enzymatic activities showed a considerable increase. In 1-month-old infants, the activities were slightly diminished. Table III presents the pancreatic enzyme activities in full term neonates who were fed formula $A$. At birth before the first feeding, the enzyme activities were relatively high, 


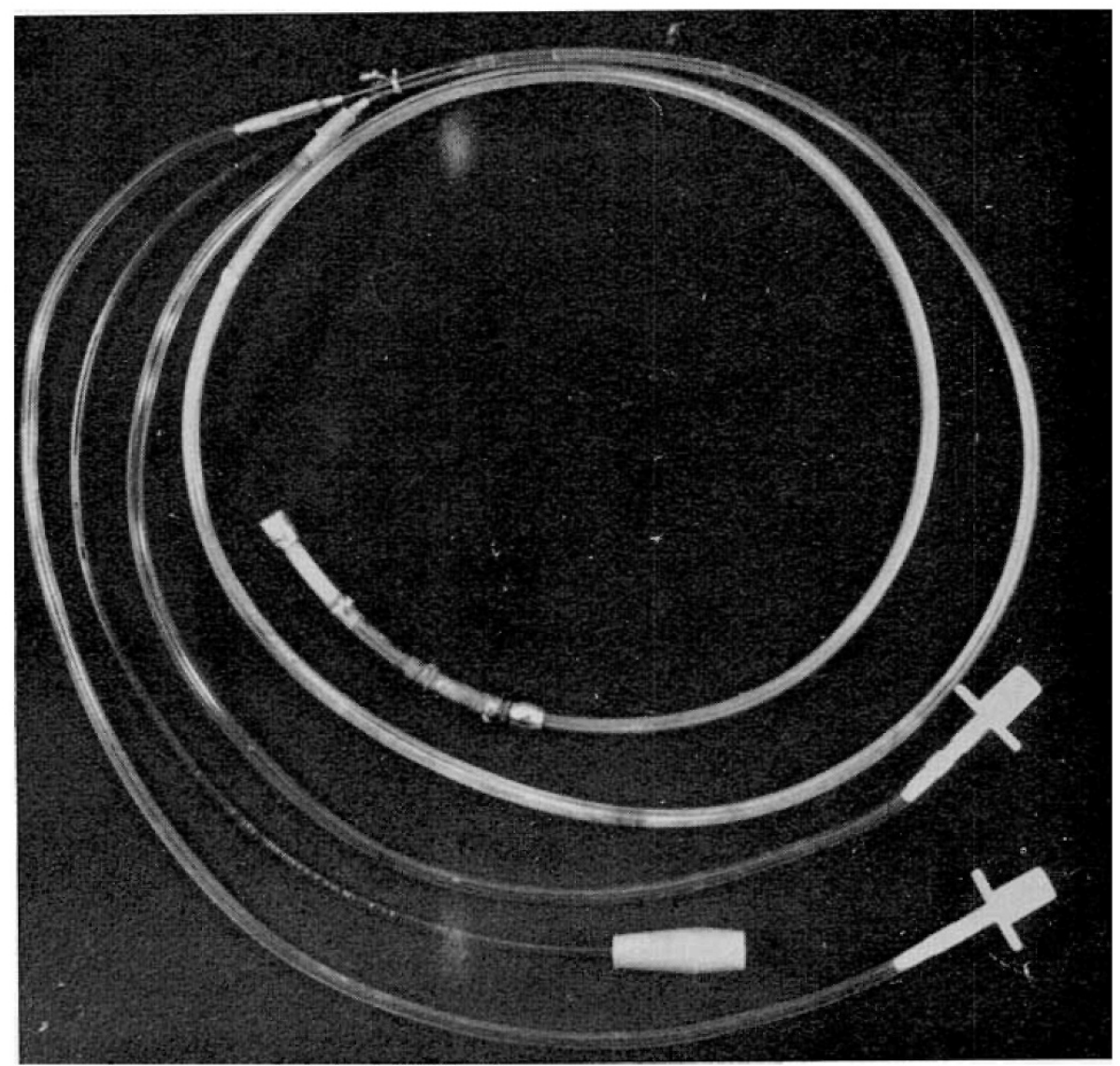

Fig. 1. Three lumen double balloon tube.

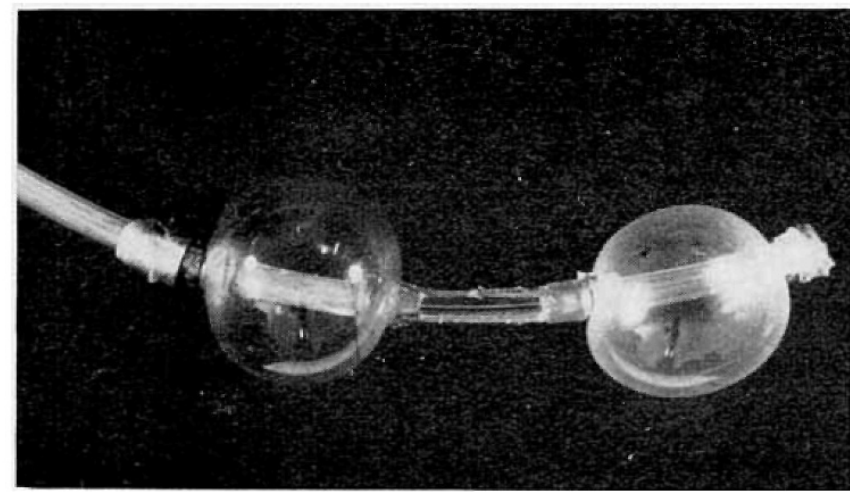

Fig. 2. End of the tube illustrated in Figure 1; the balloons are inflated with $4 \mathrm{ml}$ air. During the test they were inflated with only $2 \mathrm{ml}$ air.

although lower than in older infants and children. They diminished remarkably $24 \mathrm{hr}$ thereafter and had not returned to the initial values even 1 week later. In both premature and full term neonates, there were considerable individual variations in the exocrine pan- creatic activities. In some cases, therefore, the standard deviations of the mean values were higher than the absolute values as in those cases where the observed range includes a value of zero. Inasmuch as the number of subjects examined was small and the individual variations were quite large and not normally distributed, statistical analysis [28] of our results was done using a nonparametric statistical method. The mean values for premature and full term infants were compared using the Mann-Whitney nonparametric $U$ test for small samples [17, 29] which seems to be the most powerful of the nonparametric tests and a most useful alternative to the parametric $t$ test when the measurement is weaker than interval scaling. With this method, the differences between the mean values for premature and for full term infants were significant $(P$ $\leqslant 0.002$ ) (except in the case of $\alpha$-amylase).

Table IV presents the results obtained in various groups of premature neonates who were fed different formulas. The values for subjects who were fed for mula $A$ are those of Table II and are included here for 


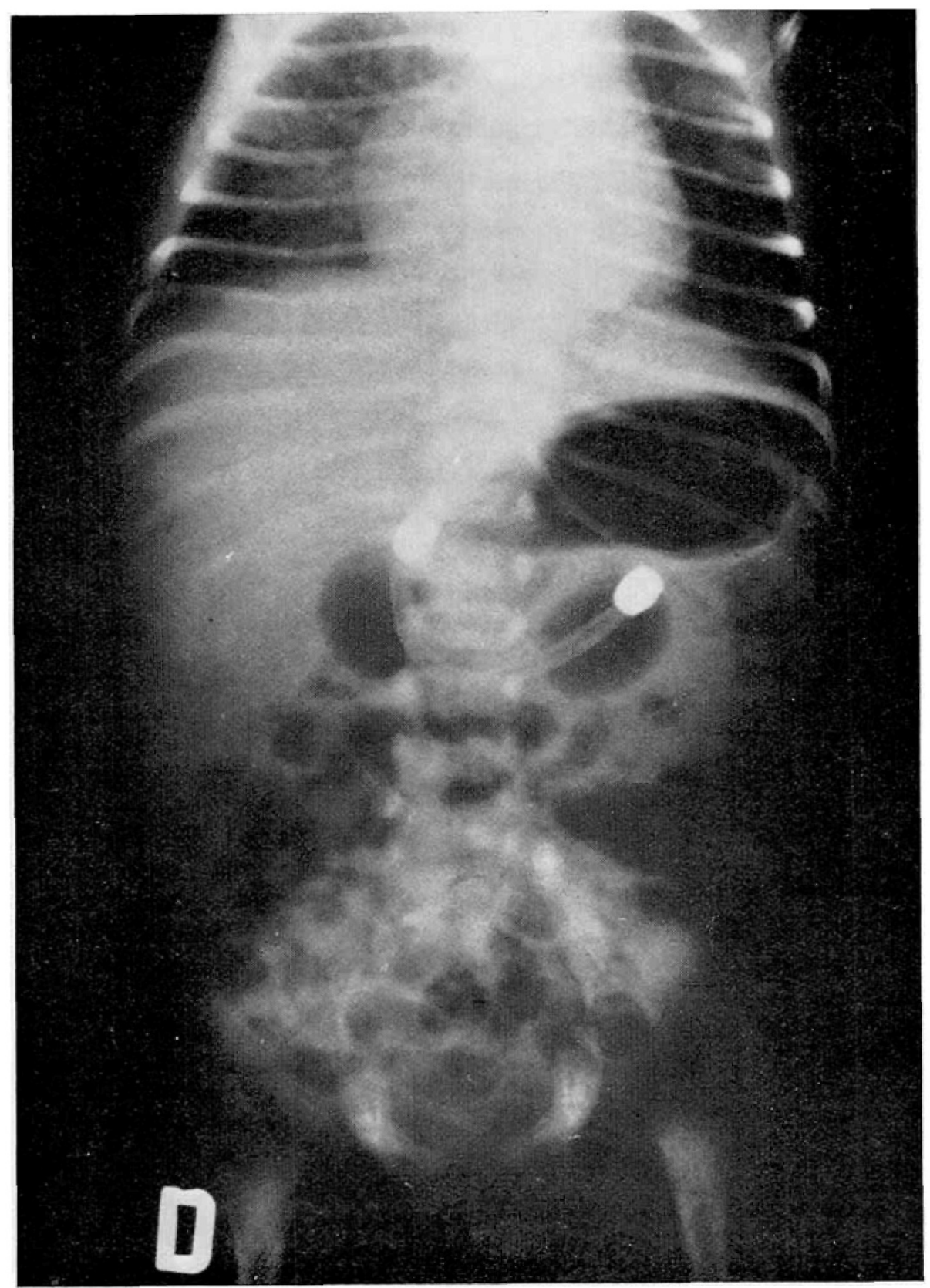

Fig. 3. Roentgenogram showing double balloon tube in position for the collection of duodenal juice. The distal silver marker is near the ligament of Treitz and the proximal one is immediately after the pylorus.

comparison. The premature neonates who were fed the starch-containing formula $B$ had a higher production of $\alpha$-amylase than did all the other subjects who were fed formulas without starch; their production of trypsin and lipase was similar to that of subjects who were fed formula $A$. Subjects who were fed formula $C$ (which contained glucose rather than starch) showed higher trypsin and lipase production than subjects who were fed either the comparatively low protein formula $A$ or the starch-containing formula $B$; their level of $\alpha$-amylase was similar to that in subjects fed starch-free formulas $A$ and $D$. Finally, subjects fed low fat formula $D$ (skimmed milk without any addition) had the highest trypsin production, $\alpha$-amylase production similar to that of other groups fed starch-free formulas $A$ and $C$, and lipase production higher than 
Table II. Pancreatic enzyme activities in premature neonates who were fed formula $A^{1}$

\begin{tabular}{|c|c|c|c|c|}
\hline Age of subjects & Volume, $\mu \mathrm{l}$ & $\alpha$-Amylase, IU & Trypsin, $\mu \mathrm{g}$ & Lipase, IU \\
\hline I week & $\begin{array}{c}822 \pm 731 \\
(167-1680)\end{array}$ & $\begin{array}{c}2.07 \pm 3.04 \\
(0.2-8.2)\end{array}$ & $\begin{array}{c}233.3 \pm 276.1 \\
(4.9-660)\end{array}$ & $\begin{array}{c}328.8 \pm 442.5 \\
(7.2-1249)\end{array}$ \\
\hline Children $^{3}$ & $\begin{array}{c}3900 \pm 1500 \\
(1800-8100)\end{array}$ & $\begin{array}{c}665 \pm 464 \\
(160-2150)\end{array}$ & $\begin{array}{c}765 \pm 535 \\
(215-2000)\end{array}$ & $\begin{array}{c}1464 \pm 1075 \\
(350-5000)\end{array}$ \\
\hline
\end{tabular}

1 Values are expressed on the basis of body weight (per kilogram) and represent means \pm 1 sD of the activities during 50 min after injections of pancreozymin and secretin. Range of values appears in parentheses.

2 Before first feeding.

3 Age range: 9 mon ths to 13 years.

Table IIL. Pancreatic enzyme activities in full term neonates who were fed formula $A^{1}$

\begin{tabular}{|c|c|c|c|c|}
\hline & Volume, $\mu \mathrm{l}$ & $\alpha$-Amylase, IU & Trypsin, $\mu \mathrm{g}$ & Lipase, IU \\
\hline 1 week & $\begin{array}{r}434 \pm 330 \\
(96-1040)\end{array}$ & $\begin{array}{c}1.29 \pm 1.29 \\
(0.1-3.0)\end{array}$ & $\begin{array}{c}96.6 \pm 102.9 \\
(5-230)\end{array}$ & $\begin{array}{c}39.9 \pm 42.1 \\
(6.2-125)\end{array}$ \\
\hline
\end{tabular}

1 Values are expressed on the basis of body weight (per kilogram) and represent means \pm 1 sD of the activities during 50 min after injections of pancreozymin and secretin. Range of values appears in parentheses.

2 Before first feeding.

${ }^{3}$ Age range: 9 months to 13 years.

Table IV. Pancreatic enzyme activities in premature infants who were fed different formulas ${ }^{1}$

\begin{tabular}{|c|c|c|c|c|c|}
\hline Formula & Number of subjects & Age of subjects & $\alpha$-Amylase, IU & Trypsin, $\mu \mathrm{g}$ & Lipase, IU \\
\hline$A$ & & l week & $2.07 \pm 3.04$ & $233.3 \pm 276.1$ & $328.8 \pm 442.5$ \\
\hline \multirow[t]{2}{*}{$B$} & 6 & Birth & $0.75 \pm 1.41$ & $31.6 \pm 32.9$ & $52.5 \pm 44.1$ \\
\hline & & 1 week & $2.83 \pm 2.68$ & $80.4 \pm 70.5$ & $105.0 \pm 75.7$ \\
\hline \multirow[t]{3}{*}{$C$} & 5 & Birth & $1.36 \pm 1.62$ & $39.5 \pm 31.2$ & $55.0 \pm 39.2$ \\
\hline & & 1 week & $0.74 \pm 0.86$ & $511.0 \pm 225.2$ & $420.0 \pm 322.0$ \\
\hline & & 1 month & $1.04 \pm 1.65$ & $1032.6 \pm 634.8$ & $834.0 \pm 520.5$ \\
\hline \multirow[t]{2}{*}{$D$} & 9 & Birth & $0.92 \pm 1.12$ & $42.7 \pm 35.6$ & $58.2 \pm 56.3$ \\
\hline & & 1 week & $1.55 \pm 1.82$ & $535.2 \pm 298.3$ & $398.7 \pm 412.3$ \\
\hline
\end{tabular}

1 Values are expressed on the basis of body weight (per kilogram) and represent means \pm 1 sD of the activities during 50 min after injections of pancreozymin and secretin. 
that of subjects fed either low protein and high fat formula $A$ or low fat and starch-containing formula $B$. In this case, too, because of the small and variable numbers of subjects studied, statistical analysis of the results by conventional method indicated that the differences in the enzymatic activities of the various groups were not statistically significant. However, calculation of the regression coefficient $b$ for each enzyme and group of patients proved that the described differences are real and not fortuitous.

\section{Discussion}

\section{Methods}

In our previous investigations of exocrine pancreas function in normal infants and children $(9,12,23)$ we could not include infants younger than 1.5-months-old because of the large dimension of the tube then available. In this study we have overcome this difficulty by using a newly manufactured smaller tube which, as it is only $1 \mathrm{~mm}$ larger than a common nasogastric feeding tube, is easily introduced into newborn infants. Exocrine pancreas function in premature and full term neonates was first evaluated by Borgström et al. [3] who, by using a test meal stimulation, demonstrated fairly good concentrations of trypsin and $\alpha$-amylase per milliliter of duodenal contents. Their results, however, are not comparable with ours, which were obtained by using hormonal stimulations and which are expressed as total output per kilogram body weight. We used hormonal stimulation by a separate single injection of pancreozymin and secretin because we consider the test meal stimulation of the exocrine pancreas to be a suitable test in clinical practice but not reliable enough for physiologic studies. Furthermore, continuous intravneous infusion of these hormones would give a more accurate evaluation of the secretory capacity of the pancreas [19], but this technique is certainly too traumatic for a newborn infant.

The results are reported as total output after pancreozymin and secretin stimulation since our aim in this work was to investigate the global function of exocrine pancreas. They are expressed per kilogram body weight in order to obtain a basis of comparison which is dependent only on the degree of gland maturation and on the rate of enzyme synthesis.

\section{Differences between Premature and Full Term Neo- nates}

At birth, enzymatic activities are significantly lower in premature than in full term infants. This result was expected since it is well known, as was demonstrated by Auricchio et al. [1] and Lieberman [11], that activities of the pancreatic enzymes gradually appear in the gland during the last month of fetal life. The results of our study indicate that premature neonates of 32- to 34-week gestational age secrete trypsin, lipase, and $\alpha$-amylase in considerable amounts which are, however, remarkably lower than those secreted by older infants and children. Twenty-four hours after birth, all the activities are lower than at birth in both premature and full term infants. This difference may be explained by the following: the first injections of pancreozymin and of secretin induce a washing-out effect of zymogen granules accumulated in the pancreas during the last month of fetal life, whereas the second injections produce a washing-out of zymogen granules accumulated during the $24 \mathrm{hr}$ after birth.

In 1-week-old infants, surprisingly, the values for fluid output and enzymatic activities are significantly higher in premature than in full term neonates. To explain this observation, it is suggested that during the first week of life the exocrine pancreas produces zymogen granules more rapidly in premature than in full term infants, probably in order to satisfy the greater functional demands for a more rapid growth.

\section{Influence of Diet upon Pancreatic Enzyme Secretion}

We chose premature neonates as subjects because they are suitable for a study of enzyme induction since (I) in the first weeks of life, as was demonstrated previously, they show a consistent change in enzyme production which might follow maturation of the gland, and (2) because only premature infants are still in the hospital and receiving a controlled diet at the age of 1 month. We used only commercial infant formulas and not purified diets which would probably give better results but which would also cause a serious nutritional disturbance in the infants. Our results demonstrate: (1) that introduction of starch to the diet from birth enhances pancreatic $\alpha$-amylase production, (2) that increase in protein content of the diet augments production of trypsin, and (3) that production of lipase is not stimulated by the administration of a relatively large amount of fat in a relatively low protein diet, but that it is stimulated by a high protein diet with very low fat content. The significance of these results to the pediatrician lies in the demonstration that varying the composition of the diet may stimulate such important functions as the synthesis of enzymes by an exocrine gland. 


\section{Summary}

Quantitative evaluations of exocrine pancreas function in neonates demonstrate that $\alpha$-amylase, trypsin, and lipase activities present at birth are lower in premature than in full term infants. In these subjects, consistent modification of exocrine pancreatic secretion seems to be induced by various constituents of the diet.

\section{References and Notes}

I. Auricchio, S., Rubino, A., ANd MürSet, G.: Intestinal glycosidase activities in the human cmbryo, fetus and newborn. Pediatrics, 35: 944 (1965).

2. Barbezat, G. O., and Hansen, J. D. L.: The exocrine pancreas and protein-calorie malnutrition. Pediatrics, 41: 77 (1968).

3. Borgström, B., Lindquist, B. and Lundh, G.: Enzyme concentration and absorption of protein and glucose in duodenum of premature infants. Amer. J. Dis. Childhood, 99: 338 (1960).

4. DAhlquist, A.: A method for the determination of amylase in intestinal content. Scand. J. Clin. Lab. Invest., $14: 145$ (1962).

5. Gs burro, D.: Variazioni enzimatiche digestive in rapporto a modificazioni qualitative della dieta. Acta Paediat. Lat., 4: 367 (1951).

6. Gomez, F., Ramos Galvan, R., Cravioto, J., and Frenk, S.: Study on the undernourished child. XI. Enzymatic activity of the duodenal contents in children with malnutrition of third degree. Pediatrics, 13: 544 (1954).

7. Grossman, M. I., Greengard, H., and Ivy, A. C.: On the mechanism of the adaptation of pancreatic enzymes to dietary composition. Amer. J. Physiol., 144: 38 (1944).

8. Guth, P. H., Komarov, S. A., Shay, H., and Style, C. Z.: Relationship between protein nitrogen, proteolytic amylolytic and lipolytic enzymes in canine pancreatic juice obtained under various conditions of stimulation. Amer. J. Physiol., 187: 207 (1956).

9. Hadorn, B., Zoppl, G., Shmerling, D. H., Prader, A., MCINTyre, I., AND ANDERson, C. M.: Quantitative assessment of exocrine pancreatic function in infants and children. J. Pediat., 73: 39 (1968).

10. Howard, F., and Yudkin, J.: Effect of dietary change upon the amylase and trypsin activities of the rat pancreas. Brit. J. Nutr., 17: 281 (1963).

11. Lieberman, J.: Proteolytic enzyme activity in fetal pancreas and meconium. Gastroenterology, 50: 183 (1966).

12. Lundh, G.: Determination of trypsin and chymotrypsin in human intestinal content. Scand. J. Clin. Lab. Invest., 9: 220 (1957).

13. Marchis-Mouren, G., Paséro, L., and Desnuelle, P.: Further studies on amylase biosynthesis by pancreas of rats fed on starch-rich or a casein-rich diet. Biochim. Biophys. Res. Commun.; 13: 262 (1963).

14. Marchis-Mouren, G., Sarda, L., and Desnuelle, P.: Purification of hog pancreatic lipase. Arch. Biochem., 83: 309 (1959).

15. MeYer, K. H., Fisher, E. H., ANd BeRnfeld, P.: L'isolement de l' $\alpha$-amylase de pancréas. Helv. Chim. Acta, 30: 64 (1947).
16. Reboud, J. P., Ben Abdeljlil, A., and Desnuelle, P.: Variation de la teneur en enzymes du pancréas de rat en function de la composition des régimes. Biochim. Biophys. Acta, 58: 326 (1962).

17. SIFGeL, S.: Nonparametric Statistics for the Behavioral Science. Intern. Stud. Ed., p. 116. (McGraw-Hill-Kogakusha Co., Ltd., Tokyo, 1956).

18. Vélghevy, P. V., and Kemény, T. T.: Protein metabolism and pancreatic function. Ciba Foundation Symposium on the Exocrine Pancreas, p. 329. (J. \& A. Churchill, Ltd., London, 1961.)

19. Wormstey, K. G.: Further studies of the response to secretin and pancreozymin in man. Scand. J. Gastroenterol. 6: 343 (1971).

20. Zoppi, G. Andreotti, G., Pajno-ferrara, F., and Gaburro, D.: Pancreozymin secretin tests in newborns (abstract). Acta Paediat. Scand., 60: 370 (1971).

21. Zopri, G., Andreotti, G., Pajno-ferraka, F., and Gaburro, D.: Function of exocrine pancreas in newborns (Abstract). Pediat. Res., 6: 65 (1972).

22. Zopri, G., Hitzig, W. H., Shmerling, D. H., Plüss, H., Hadron, B., and Prader, A.: Protein content and pancreatic enzyme activities of duodenal juice in normal children and in children with exocrine pancreatic insufficiency. Helv. Pediat. Acta, 23: 577 (1968)

23. Zolpi, G., Shmerling, D. H., Gaburro, D., and Prader, A.: The electrolyte and protein contents and outputs in duodenal juice after pancreozymin and secretin stimulation in normal children and in patients with cystic fibrosis. Acta Paediat. Scand., 59: 692 (1970).

24. The tube was kindly supplied by Argyle Medical Industries, Hounslow Road, Feltham, Middlesex, England, to whom the authors are indebted for very great help.

25. Two units per kilogram, Boots.

26. 1 IU $=$ I $\mu$ mole of substrate hydrolyzed per minute under the conditions described in the original method.

27. The preparation used for reference standard curves was Trypure (Novo Industry, Denmark) with a specific activity of 13,500 BAEE units/mg dry powder (BAEE unit = o.d.ch. of $0.001 / \mathrm{min}$ at $253 \mathrm{~nm}$ ). The substrate used was $N$-benzoylarginine ethyl ester (FLUKA AG, Switzerland).

28. Statistical calculations were kindly done by Dr. Eugenio Girelli-Bruni of the Statistic Unit of the Policlinico di Borgo Roma, Verona, to whom the authors are greatly indebted for his very useful contribution.

29. The equation used is $U=n_{1} n_{2}+n_{1}\left(n_{1}+1\right) / 2-R_{1}$, where $R_{1}=$ sum of the ranks assigned to groups whose sample size is $n_{1}$.

30. Reported in part at the annual Meeting of the European Society for Pediatric Gastroenterology, Lund, Sweden, August $1970{ }^{[20]}$ and at the annual Meeting of the European Society for Paediatric Research, Brighton, England, June, 1971 [21]

31. This work was supported by Grant no. 70.00967.04 from the Consiglio Nazionale delle Richerche.

32. Requests for reprints should be addressed to: Prof. G. Zoprr, M.D., Clinico Pediatrica della Università, Policlinico Borgo Roma, 37100 Verona, Italy.

33. Accepted for publication August 15, 1972. 